\title{
Persepsi dan Makna Tradisi Perkawinan Bajapuik pada Masyarakat Sungai Garingging Kabupaten Padang Pariaman
}

\section{Perception and Mean of Bajapuik Wedding Tradition on Garingging Riverside Society in Padang Pariaman Districs}

\author{
Zike Martha \\ Program Studi Ilmu Komunikasi, Universitas Dharma Andalas \\ Alamat: Jl. Sawahan No. 103, Simpang Haru, Padang Tim, Padang, Sumatra Barat, \\ Indonesia 25000 \\ Email: zikemartha17@gmail.com
}

\begin{abstract}
Abstrak
Persepsi dan makna tradisi adat perkawinan bajapuik pada masyarakat Sungai Garingging Kabupaten Padang Pariaman penting untuk dikaji lebih mendalam. Metode kualitatif dengan desain deskriptif, yaitu penulisan yang memberi gambaran secara cermat mengenai gejala individu atau kelompok tertentu tentang suatu keadaan dan gejala yang terjadi. Wawancara mendalam kepada informan yang dipilih secara purposive, yaitu pemimpin adat/niniak mamak, alim ulama, suami dan isteri yang baru menikah, petugas pelaksana adat bajapuik, Ketua KAN/Karapatan Adat Nagari. Data dianalisis dengan Teori Komunikasi antar Budaya. Hasil penelitian menunjukkan bahwa ada persepsi warga yang menolak dan yang menerima serta masih melakukan tradisi bajapuik. Persepsi warga Sungai Garingging tentang tradisi bajapuik (menjemput pengantin laki-laki) sebagai sebuah budaya untuk memuliakan pasangannya. Adat perkawinan Sungai Garingging Kabupaten Padang Pariaman berbeda dengan adat perkawinan daerah Minangkabau lainnya. Pemberiaan uang japuik dalam adat perkawinan masyarakat Sungai Garingging ini sangat bermakna bagi mereka. Tradisi ini tidak bermaksud merendahkan atau membeli seseorang. Pelaksanaan dan pelestarian tradisi bajapuik dalam adat perkawinan ini bukan sebuah transaksi perdagangan manusia.
\end{abstract}

Kata kunci: Pelestarian budaya; persepsi; uang japuik; makna tradisi bajapuik; adat perkawinan; Padang Pariaman

\begin{abstract}
The perception and meaning of the traditional Bajapuik marriage tradition in the Garingging River community in Padang Pariaman Regency is important to be studied more deeply. Qualitative method used with descriptive design which is writing that gives an accurate description of the symptoms of a particular individual or group of a condition and symptoms that occur. In-depth interviews with informants selected purposively, they were called; traditional leaders / niniak mamak, religious scholars, newly married husbands and wives, Bajapuik customary officers, and the head of KAN / Karapatan Adat Nagari. Data were analyzed by using intercultural communication theory. The results showed that there is a perception of residents who reject, accept, and still practice the Bajapuik tradition. The perception of the residents of Sungai Garingging about the Bajapuik tradition (picking up the groom) as a culture to honor one's partner. The marriage customs of the Garingging River in Padang Pariaman Regency are different from the marriage customs of other Minangkabau areas. The giving of japuik money in the wedding customs of the Garingging River community is very meaningful to them. The tradition does not mean to demean or buy someone. The implementation and preservation of the Bajapuik tradition in the marriage tradition is not a human trafficking transaction.
\end{abstract}

Keywords: Cultural preservation; perception; japuik money; meaning of the Bajapuik tradition; marriage customs; Padang Pariaman 
Biokultur, 2020, 9 (1): 15-31. DOI: http://dx.doi.org/10.20473/bk.v9i1.21725.

Article History:

Received August 31, 2020; Accepted September 2, 2020; Published Online September 232020

\section{Pendahuluan}

Komunikasi merupakan suatu hal yang sangat mendasar dalam kehidupan manusia. Dan bahkan komunikasi telah menjadi suatu fenomena bagi terbentuknya suatu masyarakat atau komunitas yang terintegrasi oleh informasi, di mana masing-masing individu dalam masyarakat itu sendiri saling berbagi informasi untuk mencapai tujuan bersama. Secara sederhana komunikasi dapat terjadi apabila ada kesamaan antara penyampai pesan dan orang yang menerima pesan. Senada dengan hal ini bahwa komunikasi atau communication berasal dari bahasa Latin "Communisatau dalam bahasa Inggrisnya "commun" yang artinya sama. Apabila kita berkomunikasi (to communicate), ini berarti bahwa kita berada dalam keadaan berusaha untuk menimbulkan kesamaan (Suwardi dalam Azib 2018). Komunikasi dan budaya merupakan komunikasi yang memiliki hubungan timbal balik. Budaya dapat mempengaruhi komunikasi dan sebaliknya komunikasi mempengaruhi budaya. dan budaya yang berlaku di suatu daerah akan berbeda dengan daerah yang lainnya. Pada dasarnya setiap masyarakat dalam kehidupannya akan mengalami perubahan-perubahan. Namun perubahan itu tidak dilakukan semua masyarakat. Ketika perbandingan dilakukan, dengan menelaah keadaan suatu masyarakat pada waktu dan tempat yang berbeda, ternyata tradisi bajapuik di Sungai Garingging masih dilaksanakan. Fenomena ini penting diteliti dan dikaji lebih mendalam.

Komunikasi dan budaya merupakan komunikasi yang memiliki hubungan timbal balik. Budaya dapat mempengaruhi komunikasi dan sebaliknya komunikasi mempengaruhi budaya. Menurut Andrea L. Rich dan Dennis M. Ogawa, komunikasi antar budaya adalah komunikasi antar orang-orang yang berbeda kebudayaan, misalnya antar suku bangsa, antar etnik dan ras, antar kelas sosial. (Liliweri 2013: 10). Dimana komunikasi antar budaya merupakan interaksi antar pribadi dan komunikasi yang dilakukan oleh beberapa orang yang berbeda, yang menghasilkan persepsi sama atau berbeda.

Pada dasarnya komunikasi antar budaya merupakan salah satu bidang kajian dalam ilmu komunikasi. Komunikasi antar budaya sebagai objek formal yang telah dijadikan bidang kajian sebuah ilmu tentu mempunyai teori. Teori-teori tersebut mempunyai daya guna untuk membahas masalah-masalah kemanusiaan antarbudaya yang secara khusus menggeneralisasi konsep komunikasi diantara komunikator dengan komunikan yang berbeda kebudayaan dan membahas pengaruh kebudayaan terhadap kegiatan komunikasi (Fauji, Fahyuni, Muhid, dan Fahmawati 2020). Definisi komunikasi antar budaya menurut Andrea L. Rich dan Dennis M. Ogawa adalah komunikasi antara orang-orang yang berbeda kebudayaan, misalnya antar suku bangsa, antar etnik, ras dan antar kelas sosial (Liliweri 
2013: 10-11). Dari pengertian komunikasi antar budaya di atas dapat disimpulkan bahwa komunikasi antar budaya merupakan interaksi antar pribadi dan komunikasi yang dilakukan oleh beberapa orang yang memiliki latar belakang kebudayaan yang berbeda. Akibatnya interaksi dari komunikasi yang sedang dilakukan itu membutuhkan tingkat keamanan sopan santun tertentu. Komunikasi dan budaya merupakan komunikasi yang memiliki hubungan timbal balik. Budaya dapat mempengaruhi komunikasi dan sebaliknya komunikasi mempengaruhi budaya.

Hasil penelitian sebelumnya yang berhubungan dengan komunikasi antar budaya menunjukkan bahwa ada variasi temuan terkait tradisi bajapuik. Hasil penelitian lain yang dikomparasikan adalah penelitian dari : 1) Roni (2016) dengan judul " Tradisi Uang Japuik dan Status Sosial Laki-Laki di daerah perantauan Kutabumi Kabupaten Tanggerang", 2) Savvy Dian Faizzaty (2015) dengan judul " Tradisi bajapuik dan Uang Hilang pada Perkawinan Adat Masyarakat Perantauan Padang Pariaman di Kota Malang”, 3) Ridwan Syaukani (2003) dengan judul " Perubahan Peranan Mamak dalam Perkawinan Bajapuik pada Masyarakat Hukum Adat Minangkabau di Nagari Sintuak Kecamatan Sintuak Toboh Gadang Kabupaten Padang Pariaman”. Secara rinci komparasi ini adalah sebagai berikut: 
Biokultur, Volume 9, Number 1, 2020, Page 15-31

Tabel 1 Komparasi tentang Tradisi Bajapuik

\begin{tabular}{|c|c|c|c|c|}
\hline No & $\begin{array}{l}\text { Nama/ } \\
\text { Tahun }\end{array}$ & Judul & $\begin{array}{c}\text { Hasil Penelitian } \\
\text { sebelumnya }\end{array}$ & $\begin{array}{c}\text { Perbedaan dengan } \\
\text { peneliti }\end{array}$ \\
\hline 1 & $\begin{array}{l}\text { Savvy } \\
\text { Dian } \\
\text { Faizzaty/ } \\
2015\end{array}$ & $\begin{array}{c}\text { Tradisi Bajapuik } \\
\text { dan Uang Hilang } \\
\text { Pada } \\
\text { Perkawinan } \\
\text { Adat } \\
\text { Masyarakat } \\
\text { perantauan } \\
\text { Padang } \\
\text { Pariaman di } \\
\text { Kota Malang }\end{array}$ & $\begin{array}{c}\text { Menjelaskan tentang } \\
\text { Tradisi Bajapuik dan } \\
\text { Uang Hilang. Peneliti } \\
\text { mengupas tentang } \\
\text { Tradisi Bajapuik, } \\
\text { kewajiban pihak keluarga } \\
\text { perempuan memberi } \\
\text { sejumlah uang kepada } \\
\text { pihak laki-laki sebelum } \\
\text { akad nikah } \\
\text { dilangsungkan oleh } \\
\text { masyarakat Pariaman }\end{array}$ & $\begin{array}{c}\text { Penelitian ini } \\
\text { membahas tentang } \\
\text { Tradisi Bajapuik dan } \\
\text { Uang Hilang } \\
\text { sedangkan Peneliti } \\
\text { membahas tentang } \\
\text { Persepsi Masyarkat } \\
\text { Sungai Garinggiang } \\
\text { tentang Tradisi } \\
\text { Pemberian Uang } \\
\text { Japuik dalam Adat } \\
\text { Perkawinan dan } \\
\text { Makna Tradisi Uang } \\
\text { Japuik }\end{array}$ \\
\hline 2 & $\begin{array}{l}\text { Ridwan } \\
\text { Syaukani/ } \\
2003\end{array}$ & $\begin{array}{c}\text { Perubahan } \\
\text { Peranan Mamak } \\
\text { dalam } \\
\text { Perkawinan } \\
\text { Bajapuik pada } \\
\text { Masyarakat } \\
\text { Hukum Adat } \\
\text { Minangkabau di } \\
\text { Nagari Sintuak } \\
\text { Kecamatan } \\
\text { Sintuak Toboh } \\
\text { Gadang } \\
\text { Kabupaten } \\
\text { Padang } \\
\text { Pariaman }\end{array}$ & $\begin{array}{l}\text { Menjelaskan tentang } \\
\text { Peranan Mamak dalam } \\
\text { Tradisi Bajapuik, } \\
\text { seberapa besar Mamak } \\
\text { mengumpulkan dana } \\
\text { Uang Japuik yang mana } \\
\text { peran mamak di } \\
\text { Minangkabau lebih dekat } \\
\text { kepada kemenakannya } \\
\text { dibandingkan dengan } \\
\text { seorang ayah. }\end{array}$ & $\begin{array}{c}\text { Penelitian ini } \\
\text { membahas tentang } \\
\text { pergeseran peran } \\
\text { mamak dalam } \\
\text { perkawinan bajapuik } \\
\text { dan faktor-faktor } \\
\text { yang mempengaruhi } \\
\text { perubahan peran } \\
\text { mamak tersebut } \\
\text { sedangkan peneliti } \\
\text { membahas persepsi } \\
\text { masyarakat Sungai } \\
\text { Garinggiang tentang } \\
\text { Tradisi Permberian } \\
\text { Uang Makna Tradisi } \\
\text { Uang Japuik dalam } \\
\text { Adat Perkawinan }\end{array}$ \\
\hline
\end{tabular}

Sumber: Diolah, 2020.

Rumusan masalah penelitian ini adalah bagaimana persepsi dan makna yang dipahami masyarakat Sungai Garingging Kabupaten Padang Pariaman tentang tradisi bajapuik dalam adat perkawinan. Tujuan penelitin adalah mengungkap persepsi dan makna yang dipahami masyarakat Sungai Garingging Kabupaten Padang Pariaman tentang tradisi bajapuik dalam adat perkawinan.

\section{Metode}

Metode kualitatif dengan desain deskriptif digunakan dalam penelitian ini, yaitu penulisan yang memberi gambaran secara cermat mengenai gejala individu atau kelompok tertentu tentang suatu keadaan dan gejala yang terjadi (Koentjaraningrat, 1993: 89). Menurut 
Kriyantono (2006: 69). Penulisan deskriptif bertujuan untuk membuat deskripsi yang sistematis, faktual, serta akurat mengenai fakta-fakta dan sifat objek tertentu. Biasanya peneliti telah mempunyai konsep dan kerangka konseptual, melalui kerangka tersebut peneliti melakukan operasionalisasi konsep dan menghasilkan variable serta indikatornya.

Menurut Afrizal (2008: 101), pemilihan informan untuk mendapatkan data yang relevan dengan permasalahan dan tujuan penelitian, maka pengumpulan data dilakukan dengan menggunakan teknik-teknik tertentu. Keberadaan informan merupakan instrumen penting, karena informan adalah orang yang memberikan berbagai macam informasi berkaitan dengan topik yang diteliti.

Informan dipilih dengan menggunakan teknik purposif. Informan sebagai sumber data dengan pertimbangan tertentu dianggap paling tahu tentang apa yang diharapkan, sehingga mempermudah peneliti menjelajahi situasi sosial yang diteliti. Informan merupakan orang yang perpengalaman dan berpengetahuan luas serta mendalam tentang masalah yang diteliti. Kriteria informan yang dipilih berdasarkan teknik purposive yaitu informan yang terlibat dalam tradisi bajapuik. Dalam penelitian ini yang menjadi informan adalah warga yang sudah menikah dan sedang menikah.

Niniak Mamak/pemimpin sebagai pemegang sako datuak secara turun temurun menurut garis keturunan ibu dalam sistem matrilineal. Sebagai pemimpin adat maka dia memelihara, menjaga, mengawasi, mengurusi dan menjalankan seluk beluk adat. Nazir Tanjung merupakan Niniak Mamak di Nagari Sungai Garingging. Dia adalah pemimpin dan pelindung kaumnya atau anak kemenakannya menurut sesepanjang adat. Pernikahan kemenakan baru dapat berlangsung apabila ada niniak mamak menghadiri dan menyaksikan pernikahan mereka. Apabila niniak mamak tidak menghadiri pernikahan mereka maka pernikahan mereka tidak dapat berlangsung kecuali niniak mamak berhalangan hadir seperti sakit yang tidak memungkinkan untuk menghadirinya.

Alim Ulama adalah golongan rohaniawan yang ahli agama. Sebutan yang dilekatkan pada nama seorang ulama ialah "pandito", khatib, imam atau syekh, tergantung pada besar kecil keahlian dan wibawa yang dipunyai sebagai guru agama dan pembimbing rohani masyarakat. Dt. Burhan merupakan Alim Ulama di Nagari Sungai Garingging. Dia memberikan petunjuk-petunjuk dan memandu jalannya upacara pernikahan tersebut. Ketua KAN/Karapatan Adat Nagari yang juga berfungsi menyelesaikan masalah sangketa sako, pusako, pelanggaran adat dan pelanggaran syarak.

Lokasi penelitian dipilih adalah wilayah Sungai Garinggiang/Garingging, yaitu sebuah kecamatan yang terletak di Kabupaten Padang Pariaman, Sumatera Barat, Indonesia. Kecamatan Sungai Garingging berbatasan langsung dengan Kecamatan Sungai Limau dan Kecamatan IV koto Aur Malintang. Sungai Garingging memiliki luas wilayah 99,35 km2 dan kondisi wilayah berbukit-bukit dengan ketinggian dari permukaan laut $25 \mathrm{~m}$. Jumlah penduduk sekitar 25.815 jiwa dengan jumlah rumah tangga 5.611 dan $70 \%$ dari jumlah 
penduduk bermata pencarian petani. Selain bertani, orang Sungai Garingging cenderung merantau.

\section{Hasil Penelitian dan Pembahasan}

Berdasarkan observasi pelaksanaan adat perkawinan dan wawancara awal yang telah dilakukan peneliti pada bulan Juni 2018 di Sungai Garingging Kabupaten Padang Pariaman, ditemukan bahwa tradisi masyarakat Sungai Garingging Kabupaten Padang Pariaman, pemberian uang japuik dalam adat perkawinan masih dilakukan. Selain itu peneliti menemukan sebagian masyarakat kurang pemahaman dan pengetahuannya tentang tradisi pemberian uang japuik dalam adat perkawinan. Akibatnya ketika pelaksanaan tradisi ini, menimbulkan persepsi yang berbeda di mata masyarakat baik yang bersifat positif maupun negatif. Peneliti juga menemukan masyarakat yang tidak tahu dengan makna dari tradisi pemberian uang japuik itu sendiri sehingga tradisi tersebut dianggap sebuah transaksi perdagangan manusia.

Adat perkawinan Sungai Garingging Kabupaten Padang Pariaman berbeda dengan adat perkawinan daerah Minangkabau lainnya, karena mempunyai tradisi bajapuik (menjemput pengantin laki-laki) yang mensyaratkan adanya uang japuik. Adat perkawinan ini, termasuk dalamadat nan diadatkan, karena hanya terjadi di daerah tertentu saja, dalam hal ini hanya terjadi dalam lingkup Sungai Garingging Kabupaten Padang Pariaman saja.

Falsafah Adat Minangkabau memandang bahwa suami merupakan orang datang. Dengan sistem matrilokalnya, hukum adat memposisikan suami sebagai tamu di rumah istrinya. Sebagai tamu atau orang datang, maka berlaku nilai moral datang karano dipanggia, tibo karano dijapuik (datang karena dipanggil, tiba karena dijemput). Dalam prosesi pernikahan, selalu laki-laki yang diantar ke rumah istrinya, sebagai ketulusan hati menerima, maka dijemput oleh keluarga istri secara adat. Begitupula sebaliknya, sebagai wujud keikhlasan melepas anak kemenakan maka laki-laki diantar secara adat oleh kerabat laki-laki. Karenanya laki-laki disebut juga sebagai “orang jemputan” (Welhendri 2001: 56).

Di Daerah Sungai Garingging Kabupaten Padang Pariman, saat menjemput berbeda dengan daerah lainnya. Bajapuik (japuik; Jemput) adalah tradisi perkawinan yang menjadi ciri khasdi daerah Sungai Geringing. Bajapuik dipandang sebagai kewajiban pihak keluarga perempuan member sejumlah uang atau benda kepada pihak laki-laki (calon suami) sebelum akad nikah dilangsungkan. Uang japuik adalah pemberian dari keluarga pihak perempuan kepada pihak laki-laki yang diberikan pihak perempuan pada saata cara manjapuik marapulai dan akan dikembalikan lagi pada saat mengunjungi mertua pada pertamakalinya (acara manjalang). Jadi uang jemputan (uangjapuik) adalah sejumlah pemberian berupa uang atau benda yang bernilai ekonomis yang diberikan pihak keluarga calon pengantin perempuan (anakdaro) kepada pihak calon pengantin laki-laki (marapulai) pada saat acara penjemputan calon pengantin laki-laki (manjapui kmarapulai). 
Penetapan uang japuik biasanya ditetapkan dalam acara sebelum perkawinan, biasanya mamak (paman dari pihak ibu) akan bertanya pada calon anak daro, apakah benar-benar siapakan menikah, karena biaya baralek (resepsi) beserta isinya termasuk uang japuik akan disiapkan oleh keluarga perempuan. Bila keluarganya termasuk sederhana, maka keluarga akan mempertimbangkan menjual hartapusako (hartapusaka/warisan) untuk membiayai pernikahan (Silalahi, Prihatiningsih, dan P 2018).

Terkait tradisi bajapuik ini, senada dengan pendapat Asril, Maihasni, dan Alfitri (2019), bahwa bajapuik adalah tradisi perkawinan yang menjadi ciri khas di daerah Pariaman. Bajapuik dipandang sebagai kewajiban pihak keluarga perempuan memberi sejumlah uang atau benda kepada pihak laki-laki (calon suami) sebelum akad nikah dilangsungkan. Uang jemputan ini berwujud benda yang bernilai ekonomis seperti emas dan benda lainnya. Penentuan uang jemputan dilakukan pada saat acara maresek dan bersamaan dengan penentuan persyaratan lainnya. Sedangkan untuk pemberian dilakukan pada saat menjemput calon mempelai laki-laki untuk melaksanakan pernikahan di rumah kediaman perempuan

Basri (2012) juga menjelaskan bahwa uang japuik pada umumnya berwujud benda yang bernilai ekonomis. Dalam perjalanan tradisi uang japuik ini terus mengalami perubahan mulai dari model sampai kepada wujud. Dari segi model terdapat pada uang japuik yang berwujud emas, dimana pada awalnya berupa rupiah dan ringgit emas. Karena model itu sudah ketinggalan zaman, sehingga tidak diminati masyarakat dan berubah menjadi cincin, gelang dan kalung emas. Uang japuik sendiri akan ditetapkan oleh kedua belah pihak setelah acara batimbang tando dan akan diberikan saat akad nikah oleh keluarga mempelai wanita kepada keluarga pria saat manjapuik marapulai

Selanjutnya dikatakan Basri (2012), uang japuik itu dikembalikan lagi oleh pihak laki-laki kepada pihak perempuan pada acara manjalang mintuo. Jumlah uang yang dikembalikan biasanya lebih banyak dari uang japuik sebelumnya, misalnya uang japuik Rp 1.000.000,00 dikembalikan oleh pihak laki-laki Rp 1.500.000,00 atau Rp 2.000.000,00 bagi pihak lakilaki. Nilai lebih yang diberikan kepada perempuan ini mereupakan prestise tersendiri. Keluarga laki-laki akan terasa malu dan terhina apabila nilai pengembalian uang japutan sama atau malah lebih rendah dari yang diterima.

Uang japuik mengandung makna yang sangat dalam yaitu saling menghargai antara pihak perempuan dan pihak laki-laki. Ketika pihak laki-laki tidak hanya mengembalikan dalam bentuk uang japuik, maka pihak laki-laki merasa lebih dihargai. Begitu pula pihak perempuan juga merasa lebih dihargai dengan uang dan emas yang dilebihkan nilainya dari uang japuik, saat pengembalian inilah disebut dengan uang agiah jalang.

Menurut informan niniak mamak

“...Adat perkawinan Sungai Garingging (orang Minang menyebutnya Garinggiang), Kabupaten Padang Pariaman berbeda dengan adat perkawinan daerah Minangkabau 
lainnya, karena mempunyai tradisi bajapuik (menjemput pengantin laki-laki) yang mensyaratkan adanya uang japuik. Adat perkawinan ini, termasuk dalam adat nan diadatkan, karena hanya terjadi di daerah tertentu saja, termasuk lingkup Sungai Garingging Kabupaten Padang Pariaman...”.

Di Daerah Sungai Garingging Kabupaten Padang Pariman, saat menjemput berbeda dengan daerah lainnya. Bajapuik (japuik; Jemput) adalah tradisi perkawinan yang menjadi ciri khas di daerah Sungai Garinging. Menurut informan niniak mamak ketika diwawancarai:

"...Bajapuik dipandang sebagai kewajiban pihak keluarga perempuan memberi sejumlah uang atau benda kepada pihak laki-laki (calon suami) sebelum akad nikah dilangsungkan. Uang japuik adalah pemberian dari keluarga pihak perempuan kepada pihak laki-laki yang diberikan pihak perempuan pada saat cara manjapuik marapulai dan akan dikembalikan lagi pada saat mengunjungi mertua pada pertamakalinya (acara manjalang). Jadi uang jemputan (uang japuik) adalah sejumlah pemberian berupa uang atau benda yang bernilai ekonomis yang diberikan pihak keluarga calon pengantin perempuan (anak daro) kepada pihak calon pengantin laki-laki (marapulai) pada saat acara penjemputan calon pengantin laki-laki (manjapui kmarapulai) ...”.

Dikatakan pula oleh informan niniak mamak:

“...Tradisi pemberian uang japuik adalah tradisi yang sudah turun temurun dilakukan oleh masyarakat Sungai Garinggiang Kabupaten Padang Pariaman meskipun sebagian orang berpersepsi bahwa tradisi ini merugikan pihak perempuan, dan banyak yang menganggap tradisi pernikahan adat Minangkabau ini adalah ajang membeli laki-laki untuk wanita...".

Selanjutnya dijelaskan pula oleh alim ulama:

"...Pandangan ini disebabkan oleh orang Minang memang terkenal dengan garis keturunan matrilineal atau berdasarkan garis ibu yang lebih banyak mengangkat derajat perempuan. Banyak makna yang tersimpan dari uang japuik ini. Tidak semua bermaksud merendahkan atau memang membeli seseorang. Ini bukan sebuah transaksi perdagangan manusia, hanya sebuah budaya untuk memuliakan pasangannya dengan cara masyarakat Sungai Garinggiang...”.

Penetapan uang japuik biasanya ditetapkan dalam acara sebelum perkawinan, biasanya mamak (paman dari pihak ibu) akan bertanya pada calon anak daro, apakah benar-benar siap menikah, karena biaya baralek (resepsi) beserta isinya termasuk uang japuik akan disiapkan oleh keluarga perempuan. Bila keluarganya termasuk sederhana, maka keluarga akan mempertimbangkan menjual hartapusako (hartapusaka/warisan) untuk membiayai pernikahan (Silalahi, Prihatiningsih, dan P 2018). 
Adat Istiadat adalah segala dalil dan ajaran mengenai bagaimana orang bertingkah-laku dalam masyarakat. Istilah adat istiadat seringkali diganti dengan adat kebiasaan, namun pada dasarnya artinya tetap sama. Jika mendengar kata adat istiadat biasanya aktivitas individu dalam suatu masyarakat dan aktivitas selalu berulang dalam jangka waktu tertentu. Perbedaan antara adat istiadat dan hukum adat. Suatu adat istiadat yang hidup (menjadi tradisi) dalam masyarakat dapat berubah dan diakui sebagai peraturan hukum (hukum adat).

Adat istiadat mempunyai ikatan dan pengaruh yang kuat dalam masyarakat. Kekuatan meningkatnya tergantung pada masyarakat (atau, bagian masyarakat) yang mendukung adat istiadat tersebut yang terutama berpangkal tolak pada perasaan keadilannya. Soekanto (2002). Adat istiadat ini walaupun dianggap tetap namun akan berubah di dalam suatu jangka waktu yang lama (Liputo 1985).

Kaidah-kaidah sosial yang sajak lama ada dalam masyarakat yang bermaksud untuk mengatur tata tertib masyarakat. Kaidah-kaidah ini ditaati oleh anggota-anggota persekutuan hukum. Dari uraian adat istiadat tersebut dapat dijelaskan bahwa adat istiadat adalah suatu tradisi turun temurun dari kebiasaan nenek moyang. Adat istiadat perkawinan ini sampai sekarang masih dipertahankan masyarakat untuk menjaga keanekaragaman budaya. Untuk itu penting pula dipahami tentang defenisi perkawinan.

Perkawinan juga menuntut suatu tanggung jawab, antara lain menyangkut nafkah lahir dan batin, jaminan hidup, dan tanggung jawab pendidikan anak-anak yang akan dilahirkan. Hukuman yang dijatuhkan masyarakat adat dan agama, walau tidak pernah diundangkan sangat berat. Kadangkala jauh lebih berat daripada hukuman yang dijatuhkan pengadilan agama maupun pengadilan negara. Hukuman itu tidak kentara dalam bentuk pengucilan dan pengasingan dari pergaulan masyarakat Minang. Oleh karena itu, dalam perkawinan, orang Minang selalu berusaha memenuhi semua syarat perkawinan yang lazim di Minangkabau (Amir 2010).

Sejalan dengan teori yang telah dikemukakan oleh para ahli di atas perkawinan merupakan ikatan suci yang sah yang di anjurkan oleh hukum agama dan hukum negara bagi laki-laki dan perempuan yang sudah dewasa sehat jasmani dan rohani untuk menenuhi kebutuhan cinta kasih lawan jenis dan melanjutkan keturunan tanpa menyalahi nilai dan norma yang berlaku dalam masyarakat. Sehubungan dengan kehidupan sosial adat dan budaya Masyarakat di desa Sungai Garinggiang Kabupaten Padang Pariaman maka peneliti mengemukakan dua hal yang sangat berhubungan dengan sosial adat dan budayanya tersebut yaitu menyangkut keadaan sosial dan adat istiadatnya.

Dalam kondisi sosial dan kehidupan Masyarakat Sungai Garinggiang Kabupaten Padang Pariaman, di samping sistem kekeluargaan masih kuat, juga sangat memperhatikan garis keturunan dari pihak bapaknya. Masyarakat Sungai Garingging secara garis keturunan adalah tergolong masyarakat yang sederhana akan tetapi memiliki adat yang sangat kental yang terus dijunjung hingga sekarang ini. Adat istiadat Masyarakat Sungai Garingging 
memiliki keunikan tersendiri dibandingkan etnis Minangkabau umumnya. Sebagai kawasan yang berada dalam struktur rantau, beberapa pengaruh terutama dari Aceh masih dapat ditelusuri sampai sekarang, di antaranya penamaan atau panggilan untuk seseorang di kawasan ini, misalnya ajo (lelaki dewasa, dengan maksud sama dengan kakak) atau cik uniang (perempuan dewasa, dengan maksud sama dengan kakak) sedangkan panggilan yang biasa digunakan di kawasan darek adalah uda (lelaki) dan uni (perempuan). Selain itu masih terdapat lagi beberapa panggilan yang hanya dikenal di desa ini seperti bagindo, sutan atau sidi (sebuah panggilan kehormatan buat seseorang yang telah menikah dirumah mertuanya tapi tidak dirumah orang tua kandungnya (Sjarifoedin 2011: 476). Pengertian perkawinan menurut hukum adat dapat juga diartikan sebagai suatu ikatan antara seorang laki-laki dengan seorang perempuan untuk membentuk suatu rumah tangga atau keluarga baru yang nantinya akan menghasilkan keturunan yang mana perkawinan ini bersangkutpaut dengan masalah kedudukan, harta kekayaan, dan masalah pewarisan (Setiady 2009: 222). Masyarakat yang menganut sistem kekerabatan Matrilineal mempunyai tujuan yang sama dengan sistem kekerabatan Patrilineal, dimana perkawinan adat yang dilakukan mempunyai tujuan untuk tetap mempertahankan garis keturunan ibu, mempertahankan keberlangsungan bundo kanduang dalam menjaga harto pusako yang ada di tanah Minang. Menurut informan Ketua KAN:

“...Peran mamak sangat penting, mamak harus tahu dengan pelaksanaan tradisi tapi tetap juga dengan persetujuan keluarga barulah bertemu antara kedua niniak mamak karena persetujuan telah selesai, yang pertama turun tangan tetap orang tua terlebih dahulu setelah itu baru di hubungi mamak, maka baru mamak bermusywarah dalam hal ini. Mamak kontan dengan niniak mamak daerah. Jadi orang tua mamak kontanniniak mamak nagari karena sifatnya niniak mamak itu menyetujui. Pada saat bertunangan (tukar cincin) yang melaksanakannya adalah mamak dengan mamak karena antara calon laki-laki dengan calon perempuan itu belum ada ikatan yang suci atau muhrim..."

Menurut teori, uang japuik diserahkan ketika meminang. Biasanya pihak dari laki-laki meminta uang japuik beserta hal-hal yang telah disepakati dan dibicarakan ketika merambah jalan dulu. Namun berbeda dengan yang terjadi dilapangan. Menurut ketua KAN yaitu:

“...wakatu penyerahan uang japuik tu, manuruik persetujuan kedua belah pihak. Tapi nan pastinyo uang japuik ko diagiah, sabalun pesta perkawinan dilaksanakan. Harus salasai nek e uang japuik tu. Kalau pado wakatu maminang tu buliah sajo. Sabalun pesta perkawinan tu kok dapek alah lunas nek e. Buliah pas maminang tu diagiahan. Terserah kadua belah pihak lah tu. Kau pihak padusi istilahnyo alah bersedia nyo pas tibo maminang lah siap dek nyo sakali bisa...".

“...menunggu persetujuan kedua belah pihak. Bisa diserahkan ketika meminang. Pokoknya uang jemputan itu harus selesai atau lunas sebelum pesta pernikahan. Dibayarkan ketika meminang boleh-boleh saja. Minimal sebelum pesta pernikahan itu 
harus lunas. Ketika meminangpun juga boleh dilunaskan. Terserah kedua belah pihak. Kalau pihak perempuan mau membawa uang jemputan saat meminang juga tidak apaapa..."

Selanjutnya proses perhelatan. Dalam proses ini mamak menjadi satu satunya penyambut tamu yang datang. Selain itu mamak juga bertugas menyampaikan undangan kepada pemuka-pemuka masyarakat untuk menghadiri acara perhelatan tersebut.

Menurut informan pemuka masyarakat;

"lah tantu hari alek atau hari pesta tu, nan mamak harus standby disinan".

"jika hari pesta sudah ditentukan. Yang namanya mamak harus ada disana...

bahwasan nya uang japuik yang dikembalikan pas acara bersalam ini hanya di daerahdaerah tertentu. bahwa pihak perempuan mendapat balasan pada waktu mempelai perempuan manjalang (mengunjungi) rumah laki-laki yang dilaksanakan secara adat dan merupakan acara puncak untuk menutup kedua pesta yang biasanya bernilai lebih dari hadiah perkawinan itu yang bernama baleh jalang. Baleh jalang bagi laki-laki mungkin agak memberatkan namun si laki-laki tidak membayar dengan sendiri tetapi dibantu oleh karib kerabat.

Penentuan Uang Japuik hasil temuan di lapangan berdasarkan fokus penlitian, dipengaruhi oleh gelar dari calon mempelai laki-laki. Hal ini sesuai dengan wawancara dari ketua Kerapatan Adat Nagari (KAN) Sungai Garingging Kabupaten Padang Pariaman. Pada saat sekarang ini besaran uang japuik tergantung pendidikan dan pekerjaan dari calon mempelai laki-laki. Semakin tinggi pendidikan seseorang maka uang japuiknya semakin tinggi. Begitupun dengan pekerjaan, semakin bagus pekerjaannya maka uang japuiknya pun semakin besar.

Menurut informan ibu pihak perempuan;

"biaso e kalau pendidikan e tinggi 100 ameh gai ado. Tentara itu urang e, urang sungai rantai tu sanghi a, tentara nyo. 100 ameh uang japuik e. Kalau urang biaso 5 juta palingan e nyeh. Kayak tukang ojek randah tu tukang baruak agak randah saketak nak".

"biasanya kalau orang nya pendidikan tinggi 100 emas pun ada, pekerjaannya tentara. Dulu pernah orang Sungai Rantai, 100 emas uang jemputannya. Kalau orang biasa sekitar 5 jutaan. Seperti tukang ojek tukang beruk panjat kelapa) agak rendah uang jemputannya".

Dijelaskan informan Alim Ulama;

'Uang japuik diberikan bila terjadi perkawinan antara dua orang asal Padang Pariaman. Hal ini bersifat wajib untuk menghargai niniak mamak. Bila perkawinan terjadi antara laki-laki Pariaman dan wanita yang bukan berasal dari Padang Pariaman, maka 
pemberian uang japuik sendiri tergantung keluarga kedua belah pihak, apakah tetap dilaksanakan atau tidak. Ada keluarga Padang Pariaman yang tetap kukuh harus menyertakan uang japuik dalam perkawinan, ada pula yang tidak. Bila keluarga masih juga bersikeras, bisa-bisa batal menikah, atau mungkin mereka tidak akan menikah sesuai dengan adat Padang Pariaman”.

Tradisi bajapuik merupakan tradisi yang sudah turun temurun dilaksanakan di Sungai Garingging Kabupaten Padang Pariaman. Apabila ada masyarakat yang tidak melaksanakan tradisi ini maka akan diberikan sanksi, seperti sanksi moral. Dimana keduanya bisa gagal menikah. Dan di cap sebagai orang yang tidak beradat.

Setiap tradisi yang dilakukan oleh suatu masyarakat tentu terrdapat nilai- nilai yang terkandung didalamnya begitupun dengan tradisi uang japuik. Bapak Nazer selaku orang yang dituakan dalam masyarakat menuturkan nilai yang terkandung dalam pelaksanaan tradisi ini.

"makna tradisi bajapuik ini untuk saling menghargai pihak dari calon mempelai lakilaki dan pihak dari calon mempelai perempuan. Karena sudah jelas. Uang japuik berbalik kembali. Saat pihak calon mempelai perempuan ke rumah calon mempelai laki-laki. Pihak dari mempelai perempuan akan diberikan emas atau berupa uang”.

Dalam tahapan proses pelaksanaan tradisi bajapuik dalam perkawinan ini terlihat dominannya peran niniak mamak sangat penting. Tahap awalnya pada saat marambah jalan sampai selesainya acara perhelatan. Prosesi awal dari suatu upacara perkawinan di Sungai Garingging Kabupaten Padang Pariaman disebut marambah jalan. Istilah ini seperti maresek, maratok tango, malensok bangka. Namun arti dan pelaksanaanya sama. Bagi orang tua yang mempunyai gadis atau bagi niniak mamak yang mempunyai kemenakan akan mempunyai beban dan tanggung jawab yang berat. Tanggumg jawab tersebut adalah mencarikan jodoh dan melaksanakan perkawinan anak atau kemenakannya menurut adat. Hal ini menurut tradisi yang telah turun temurun sejak dulu sampai sekarang bahwa dalam mencarikan jodoh atau kemenakannya yang perempuan terletak ditangan orang tua atau mamak.

Sebagaimana diketahui, bahwa yang disebut merambah jalan yaitu suatu kegiatan yang dilakukan kedua belah pihak dalam memperhitungkan perjodohan anak atau kemenakannya. Pelaksanaan dalam merambah jalan ini dilakukan di rumah pihak laki-laki. Dalam kegiatan merambah jalan yang ikut ke rumah laki-laki antara lain ibu, mamak, bapak, atau bako. Pembicaraan pada pertemuan itu adalah berkisar pada persetujuan dan persyaratan yang harus dipenuhi oleh kedua belah pihak. Peran mamak dalam proses meminang di Sungai Garingging diawali dengan proses adat antara lain: 


\section{Berkampung-kampungan}

Berkampung-kampungan adalah istilah prosesi upacara perkawinan di Sungai Garingging. Berkampung-kampungan berarti berkumpul untuk bermusyawarah. Sebagaimana yang telah diuraikan diatas bahwa pelaksanaan helat atau upacara perkawinan merupakan suatu pekerjaan ini membutuhkan tidak saja biaya yang tinggi, tetapi juga butuh tenaga. Kronologis berkampung-kampungan ini adalah orang yang akan berhelat mengundang seluruh kaum kerabat dan orang nagari untuk hadir. Setiap orang yang diundang setelah mendengar kata berkampungan secara moral ia telah terlibat artinya ia sebagai orang yang diundang diharuskan datang menghadiri undangan tersebut. Setelah hari yang ditentukan datang, maka yang mengundang menyediakan tempat mufakat, makanan dan minuman. Duduk didalam rumah dalam satu ruangan yang telah disediakan. Peran mamak dalam berkampung-kampungan adalah dalam pernikahan sesama orang pariaman. Peran mamak dalam berkampung-kampungan hampir sama. Meminang calon menantu. Ketika dirumah perempuan, setelah disepakati semua yang dirundingkan saat bakampungan, salah satu rundingan itu adalah menentukan hari untuk datang meminang.

\section{Hari baralek / Proses perhelatan}

Rentetan upacara perkawinan puncaknya adalah pelaksanaan upacara perkawinan atau lebih populer dengan istilah hari baralek. Pada hari berhelat itu baik di rumah pengantin perempuan maupun di rumah pengantin laki-laki disibukkan dengan berbagai pekerjaan. Sebagaimana telah diuraikan di atas bahwa saat berhelat semua unsur dalam baik secara masyarakat, atau secara kekerabatan akan terlibat. Keterlibatkan semua unsur ini sesuai dengan fungsinya masing-masing. Melibatkan orang-orang di lingkungan keluarga dan masyarakat dimulai sejak mempersiapkan sarana penunjang.

\section{Penentuan Uang Japuik}

Muchtaruddin (1976), mengatakan ada beberapa versi asal usul tradisdi bajapuik Asal mula dari tradisi bajapuik ini salah satunya adalah daerah Tiku dan berkembang ke Sungai Garingging. Dalam tradisi perkawinan di Sungai Garingging dikenal dengan istilah uang japuik. Uang japuik merupakan pemberian dari pihak perempuan kepada pihak laki-laki. Setelah pelaksanaan tradisi bajapuik, disaat perhelatan pihak laki-laki menyerahkan sebagian uang yang telah diberikan kepada mempelai perempuan yang mana penyerahan tersebut dilakukan saat diadakan proses manjalang (kungjungan) yang dilakukan oleh kunjungan dari mempelai perempuan ke rumah mempelai laki-laki.

Berdasarkan bahwa pelaksanaan tradisi bajapuik, maka sekarang pelaksanaan tradisi bajapuik tidak seketat pada zaman dahulu. Ketika akan dilakukan perkawinan uang japuik bagi sebagian masyarakat Sungai Garingging hanya dilakukan sekedar untuk melaksanakan adat saja, sehingga besarnya pun terkadang tidak dipengaruhi oleh tiga faktor tahapan diatas. Bahkan ada kejadian yang mana uang japuik itu berasal dari calon mempelai lakilaki yang diserahkan terlebih dahulu kepada calon perempuan sebelum tradisi japuik dilaksanakan. Pada zaman sekarang, nilai uang japuik bisa diganti dengan uang rupiah biasa dan emas. Besar uang japuik misal profesinya orang biasa, dia dijemput dengan uang 
senilai Rp.15.000.000, 00, sedangkan bila ia sarjana, guru, dokter, polisi, dijemput dengan uang senilai Rp. 50.000.000,00.

Tabel 2 Penetapan Besar Uang Jemputan Informan

\begin{tabular}{llllll}
\hline No. & Nama Istri & Nama Suami & Pekerjaan Suami & Sebab Pernikahan & $\begin{array}{l}\text { Jumlah Uang } \\
\text { Jemputan (Rp) }\end{array}$ \\
\hline 1. & Suarni & Zaher & Guru & Dijodohkan & 30.000 .000 \\
2. & Yusri & Puji & Wiraswasta & Pacaran & 15.000 .000 \\
3. & Marnis & Budi & Polisi & Dijodohkan & 50.000 .000 \\
\hline
\end{tabular}

Sumber: Data primer.

Dari tabel 2 dapat dilihat jumlah uang japuik yang diberikan oleh pengantin perempuan kepada pengantin laki-laki bervariasi, hal itu di dapatkan dari hasil kesepakatan kedua belah pihak keluarga yang akan melaksanakan perkawinan. Selain dipengaruhi oleh pendidikan, pekerjaan, orang tua pihak perempuan bila merasa sanggup untuk memenuhi permintaan besarnnya karena sebelum menikah keluarga perempuan telah mempersiapkan segala kebutuhan yang diperlukan yang digunakan saat akan melaksanakan perkawinan.

Ada juga perkawinan Padang Pariaman, yang pemberian uang japuiknya, pelaksanaannya sedikit diberi kelonggaran. Uang japuik tetap diberikan, namun hanya formalitas saja. Bila ada ninik mamak yang bertanya berapa uang japuiknya, maka bisa dijawab dan orangorang yang menghadiri pesta pernikahan telah melihat bahwa memang marapulai diberi uang japuik, walaupun sebenarnya, uang tersebut hanya didengungkan saja, tapi kenyataannya tak ada.

Setiap tradisi yang dilakukan oleh suatu masyarakat tentu terrdapat nilai- nilai yang terkandung didalamnya begitupun dengan tradisi uang japuik. Ada beberapa nilai yang terkandung dalam tradisi bajapuik yakni nilai sosial, budaya, dan agama. Nilai sosial yang ada pada adat tradisi uang japuik ialah untuk menghargai pihak laki-laki yang akan menjadi orang pedatang di keluarga pihak perempuan, agar wibawanya seorang laki laki itu yang akan menjadi suaminya dianggap ada dan untuk menaikkan harkat dan martabat pihak lakilaki sehingga mereka dijemput secara adat. Nilai budaya pada tradisi ini merupakan tradisi yang unik yang hanya dimiliki daerah Pariaman dan diluar Pariaman khususnya Sumatera Barat tidak ada tradisi bajapuik dengan menggunakan uang jemputan. Nilai agama yang ada pada adat tradisi uang japuik ini adalah, bahwa dulu masukknya Islam ke Pariaman berpengaruh terhadap tradisi ini. Islam masuk dan berkembang pada suatu daerah, maka tradisi bajapuik menjadi tradisi yang diikuti oleh penyebaran nilai agama. Islam dalam pandangan orang Minangkabau adalah sebagai penyempurnaan adat, "adat basandi syarak, syarak basandi kitabullah, syarak mangato adat mamakai".

Dalam tradisi bajapuik peran mamak sangat dominan di Sungai Garingging Kabupaten Padang Pariaman. Seperti peran mamak dalam merambah jalan, mamak berperan sebagai pemegang keputusan. Disana proses perkawinan bajapuik tidak akan berjalan sebelum persetujuan dari mamak. Jika sudah disepakati kapan pelaksanaan untuk meminang didalam 
merambah jalan maka peran mamak berikutnya adalah musyawarah dengan sanak famili dan orang-orang senagari untuk menyampaikan bahwa akan diadakan pernikahan yang dinamakan acara berkampung-kampungan. Lanjut ketahap berikutnya, mamak berperan dalam peminangan. Tugas mamak menyambut tamu yang akan datang dengan alek nan datang. Secara adat berunding sampai tercapainya kesepakatan kedua belah pihak seperti penentuan besarnya uang japuik dan pelaksanaan hari perhelatan.

Dalam penentuan uang japuik mamak berperan aktif. Mamak mempunyai kriteria-kriteria dalam menentukan jumlahnya. Penentuan uang japuik di Sungai Garingging Kabupaten Padang Pariaman dipengaruhi oleh gelar dari calon mempelai laki-laki. Adapun gelarnya, sidi, sutan, bagindo. Gelar yang paling mahal jemputnya adalah sidi, ini dikarenakan orang yang bergelar sidi merupakan keluarga bangsawan. Pada saat sekarang ini uang japuik tergantung pendidikan dan pekerjaan dari calon mempelai laki-laki. Semakin tinggi pendidikan seseorang maka uang japuiknya semakin tinggi, begitupun dengan pekerjaanya, semakin bagus dan semakin tinggi jabatan seseorang dalam pekerjaanya maka uang japuiknya pun semakin besar. Selain itu uang japuik juga dipengaruhi oleh status sosial.

\section{Simpulan}

Nampak bahwa tradisi bajapuik sangat bermakna bagi masyarakat Sungai Garingging Kabupaten Padang Pariaman, karena tradisi ini mengandung tiga nilai, yaitu pertama nilai sosial, nilai untuk menghargai pihak dari calon mempelai laki-laki karena pihak laki-laki akan menjadi pendatang di keluarga calon mempelai perempuan; kedua nilai budaya, yaitu tradisi yang unik, yang hanya ada di daerah Pariaman khususnya di Sungai Garingging Kabupaten Padang Pariaman; ketiga nilai agama yaitu sebagai penyempurnaan adat.

Bagi masyarakat Sungai Garingging Kabupaten Padang Pariaman, agar lebih memahami bahwa pengadaan tradisi bajapuik adalah untuk membantu calon mempelai laki-laki membiayai bahtera rumah tangganya maka tidak perlu berlebihan, tidak memberatkan pihak perempuan terlebih lagi batalnya perkawinan. Sementara itu bagi masyarakat di luar Sungai Garingging Kabuparten Padang Pariaman, hendaknya berfikir positif terhadap suatu adat yang berlaku di suatu daerah. Karena adat ini dulunya ada karena mempertimbangkan kemashlahatan umat. Termasuk tradisi bajapuik khususnya di daerah Sungai Garingging Kabupaten Padang Pariaman yang mempunyai hakikat baik demi mensejahterakan manusia.

Para tokoh adat diharapkan memberikan penjelasan mengenai kearifan lokal yang terdapat dalam tradisi uang japuik ini, karena sebagian dari masyarakat kurang mengetahui dan memahaminyanya, sehingga masyarakat yang berpersepsi kurang baik terhadap tradisi ini dapat ditepis. Kajian tentang fenomena tradisi bajapuik dan pengaruh Islam terhadap tradisi bajapuik penting dilakukan. 


\section{Daftar Pustaka}

Afrizal (2014) Penelitian Kualitatif; Sebuah Upaya Mendukung Penggunaan Penelitian Kualitatif Dalam Berbagai Disiplin Ilmu. Jakarta: PT. Raja Grafindo Persada.

Amir MS (2010) Adat MinangKabau; Pola Dan Tujuan Hidup Orang Minang. Jakarta: PT. Mutiara Sumber Widya.

Asril NM, Maihasni, dan Alfitri (2019) Solusi Konflik Peran Perempuan Minangkabau (Kasus Perawat yang Melanjutkan Pendidikan ke Perguruan Tinggi). Jurnal Antropologi: Isu-Isu Sosial Budaya, 21 (2): 194-201.

Azib Z (2018) Gaya Hidup dan Pola Komunikasi Pendaki Gunung di Kalangan Pondok Belantara Adventure Riau Kota Pekanbaru. Skripsi. Universitas Islam Riau.

Basri (2012) In VitroAntibacterial Activity of Galls of Quercus infectoria Oliver against Oral Pathogens. Evidance-Based Complementary and Alternative Medicine. https://doi.org/10.1155/2012/632796.

Fauji I, Fahyuni EF, Muhid A, Fahmawati ZN (2020) Implementing Child-Friendly Teaching Methods to Improve Qur'an Reading Ability. Jurnal Pendidikan Islam, 6 (2): 69-78. https://doi.org/10.15575/jpi.v6i1.8078.

Koentjaraningrat (1993) Metode-metode Penelitian Masyarakat. Gramedia Pustaka Utama: Jakarta.

Kriyantono R (2006) Teknis Praktis Riset Komunikasi, Edisi Cetakan Kesatu. Jakarta: Kencana Prenada Media Group.

Liliweri A (2009) Makna Budaya dalam Komunikasi Antar Budaya. Yogyakarta: PT LkiS Printing Cermelang.

Liputo M (1985) Empat Aspek Adat Daerah Gorontalo. Gorontalo: Pemda Kabupaten Daerah Tingkat II.

Muchtaruddin (1976) Kawin Bajapuik Menurut Adat Pariaman. Padang.

Syaukani R (2003) Perubahan Peranan Mamak Dalam Perkawinan Bajapuik pada Masyarakat Hukum Adat Minangkabau di Nagari Sintuak Kecamatan Sintuak Toboh Gadang Kabupaten Padang Parianian. Tesis. Universitas Diponegoro. 
Faizzaty SD (2015) Tradisi Bajapuik dan Uang Hilang Pada Perkawinan Adat Masyarakat Perantauan Padang Pariaman di Kota Malang dalam Tinjauan 'Urf. Tesis. Universitas Islam Negeri Maulana Malik Ibrahim Malang.

Soekanto S (2002) Sosiologi Suatu Pengantar. Jakarta: Raja Persada.

Setiady T (2009) Intisari Hukum Adat Indonesia (Dalam Kajian Kepustakaan). Bandung: Alfabeta.

Silalahi RR, Prihatiningsih W, dan P RLMP (2018) Hubungan Antara Komunikasi Telemarketing Asuransi dengan Sikap Calon Pelanggan terhadap Telemarketer. MetaCommunication, 3 (2): 132-145.

Sjarifoedin A (2014) Minangkabau: Dari Dinasti Iskandar Zulkarnain Sampai Tuanku Imam Bonjol. Jakarta: PT Gria Media Prima.

Undang-undang perkawinan Republik Indonesia Nomor 1 Tahun 1974.

Welhendri (2010) Matrilokal dan Status Perempuan dalam Tradisi Bajapuik. Yogyakarta: Galang Press. 